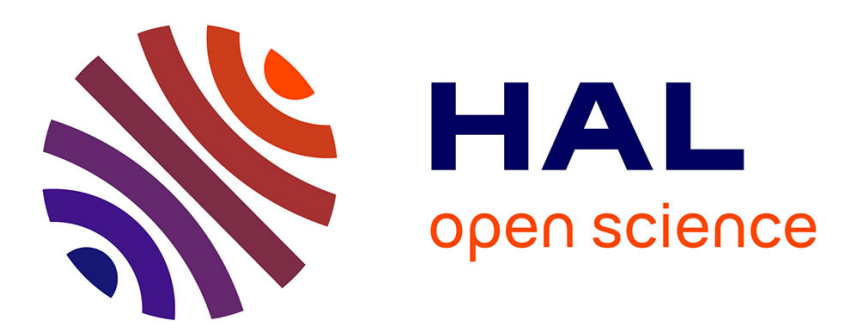

\title{
Carbon nanotubes-Fe-alumina nanocomposites. Part I: influence of the Fe content on the synthesis of powders
}

\author{
Alain Peigney, Christophe Laurent, O. Dumortier, Abel Rousset
}

\section{To cite this version:}

Alain Peigney, Christophe Laurent, O. Dumortier, Abel Rousset. Carbon nanotubes-Fe-alumina nanocomposites. Part I: influence of the Fe content on the synthesis of powders. Journal of the European Ceramic Society, 1998, vol. 18, pp. 1995-2004. 10.1016/S0955-2219(98)00141-1 . hal00959264

\section{HAL Id: hal-00959264 \\ https://hal.science/hal-00959264}

Submitted on 14 Mar 2014

HAL is a multi-disciplinary open access archive for the deposit and dissemination of scientific research documents, whether they are published or not. The documents may come from teaching and research institutions in France or abroad, or from public or private research centers.
L'archive ouverte pluridisciplinaire HAL, est destinée au dépôt et à la diffusion de documents scientifiques de niveau recherche, publiés ou non, émanant des établissements d'enseignement et de recherche français ou étrangers, des laboratoires publics ou privés. 


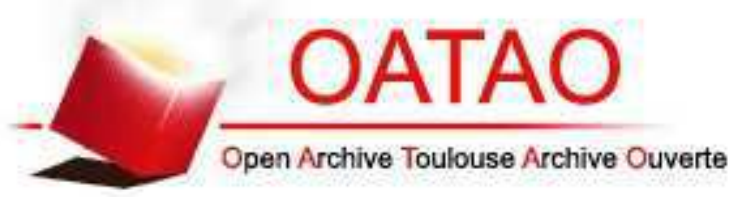

\section{Open Archive TOULOUSE Archive Ouverte (OATAO)}

OATAO is an open access repository that collects the work of Toulouse researchers and makes it freely available over the web where possible.

This is an author-deposited version published in : http://oatao.univ-toulouse.fr/ Eprints ID : 11169

To link to this article : doi:10.1016/S0955-2219(98)00141-1

URL : http://dx.doi.org/10.1016/S0955-2219(98)00141-1

To cite this version : Peigney, Alain and Laurent, Christophe and Dumortier, O. and Rousset, Abel Carbon nanotubes-Fe-alumina nanocomposites. Part I: influence of the Fe content on the synthesis of powders. (1998) Journal of the European Ceramic Society, vol. $18\left(\mathrm{n}^{\circ}\right.$ 14). pp. 1995-2004. ISSN 0955-2219

Any correspondance concerning this service should be sent to the repository administrator: staff-oatao@ listes-diff.inp-toulouse.fr 


\title{
Carbon Nanotubes-Fe-Alumina Nanocomposites. Part I: Influence of the Fe Content on the Synthesis of Powders
}

\author{
A. Peigney, Ch. Laurent,* O. Dumortier and A. Rousset \\ Laboratoire de Chimie des Matériaux Inorganiques, ESA CNRS 5070, Université Paul-Sabatier, \\ F 31062 Toulouse cedex 4, France
}

\begin{abstract}
Oxides based on $\alpha$-alumina and containing various amounts of $\mathrm{Fe}(2,5,10,15$ and 20 cat\%) were prepared by decomposition and calcination of the corresponding mixed-oxalates. Selective reduction of the oxides in a $\mathrm{H}_{2}-\mathrm{CH}_{4}$ atmosphere produces nanometric $\mathrm{Fe}$ particles which are active for the in-situ nucleation and growth of carbon nanotubes. These form bundles smaller than $100 \mathrm{~nm}$ in diameter and several tens of micrometers long. However, the carbon nanotubes- $\mathrm{Fe}-\mathrm{Al}_{2} \mathrm{O}_{3}$ nanocomposite powders may also contain Fe carbide nanoparticles as well as undesirable thick, short carbon tubes and thick graphene layers covering the $\mathrm{Fe} / \mathrm{Fe}$ carbide nanoparticles. The influence of the $\mathrm{Fe}$ content and the reduction temperature on the composition and micro/ nanostructure of the nanocomposite powders have been investigated with the aim of improving both the quantity of nanotubes and the quality of carbon, i.e. a smaller average tube diameter and/or more carbon in tubular form. A higher quantity of carbon nanotubes is obtained using $\alpha-\mathrm{Al}_{1 \cdot 8} \mathrm{Fe}_{0.2} \mathrm{O}_{3}$ as starting compound, i.e. the maximum $\mathrm{Fe}$ concentration $(10 \mathrm{cat} \%)$ allowing to retain the monophase solid solution. A further increase in $\mathrm{Fe}$ content provokes a phase partitioning and the formation of a $\mathrm{Fe}_{2} \mathrm{O}_{3}$-rich phase which upon reduction produces too large $\mathrm{Fe}$ particles. The best carbon quality is obtained with only $5 \mathrm{cat} \% \mathrm{Fe}\left(\alpha-\mathrm{Al}_{1.9} \mathrm{Fe}_{0.1} \mathrm{O}_{3}\right)$, probably because the surface $\mathrm{Fe}$ nanoparticles formed upon reduction are a bit smaller than those formed from $\alpha$ $\mathrm{Al}_{1.8} \mathrm{Fe}_{0.2} \mathrm{O}_{3}$, thereby allowing the formation of carbon nanotubes of a smaller diameter. For a given Fe content $(\leq 10 \mathrm{cat} \%)$, increasing the reduction temperature favours the quantity of nanotubes because
\end{abstract}

\footnotetext{
*To whom correspondence should be addressed.
}

of a higher $\mathrm{CH}_{4}$ sursaturation level in the gas atmosphere, but also provokes a decrease in carbon quality.

\section{Introduction}

Since their discovery by Iijima, ${ }^{1}$ carbon nanotubes have emerged as potentially attractive materials for the reinforcement of ceramics. Indeed, theoretical as well as experimental studies ${ }^{2-7}$ point out that carbon nanotubes have excellent mechanical characteristics. Carbon nanotubes are commonly prepared by arc-discharge between carbon electrodes in inert gas atmosphere. ${ }^{1,8}$ Transition metals such as iron or cobalt can be used as catalysts during the arc-discharge to increase both the quantity and length of the tubes and to favour the formation of single-shell nanotubes. ${ }^{9-14}$ However, the soobtained product is a mixture of carbon nanotubes and several other carbon forms, including much amorphous carbon and carbon nanoparticles. A purification has to be conducted but it decreases the nanotube yield to about $2 \% .{ }^{15}$ Recently, 'ropes' of single-wall carbon nanotubes have been obtained by an adapted laser-ablation technique. ${ }^{16,17}$

Other methods producing carbon filaments amongst which are some autenthic nanotubes are the catalytic decomposition of hydrocarbons, ${ }^{18-22}$ metallocenes $^{23}$ and the disproportionation of $\mathrm{CO}^{24-26}$ on small metal particles $(\mathrm{Fe}, \mathrm{Co}, \mathrm{Ni}, \mathrm{Cu}$, $\mathrm{Mo}, \mathrm{Pt}$ ). Several mechanisms have been proposed for the formation of tubular carbon species ${ }^{26-29}$ by these methods, notably stressing that the metal particles are active for nanotube nucleation and growth only if they are sufficiently small $(\leq 20 \mathrm{~nm})$ and that the minimal tube internal diameter that 
can be obtained is that of the catalytic particle. In order to maximize the nanotube yield with respect to other forms of carbon, several authors investigated the influence of the temperature and of the nature of both the catalyst and the treatment atmosphere. ${ }^{20,24,29,30}$ Dai et al. ${ }^{26}$ have prepared single-wall carbon nanotubes ranging from 1 to $5 \mathrm{~nm}$ in diameter by disproportionation of $\mathrm{CO}$ on Mo particles a few nanometers in size. Using a zeolite-supported Co catalyst, Ivanov et al. ${ }^{20}$ and Hernadi et al. ${ }^{31}$ reported carbon tubes only $4 \mathrm{~nm}$ in diameter as well as $60 \mathrm{~mm}$ long tubes, but they point out that the longest tubes are also the thickest.

In previous works, ${ }^{32-39}$ we have prepared metaloxide nanocomposite powders by selective reduction in hydrogen of oxide solid solutions. In these materials, the metal particles $(\mathrm{Cr}, \mathrm{Fe}, \mathrm{Co}, \mathrm{Ni}$ and their alloys) are generally smaller than $10 \mathrm{~nm}$ in diameter and are located both inside and at the surface of the matrix grains $\left(\mathrm{Al}_{2} \mathrm{O}_{3}, \mathrm{Cr}_{2} \mathrm{O}_{3}, \mathrm{MgO}\right.$, $\left.\mathrm{MgAl}_{2} \mathrm{O}_{4}\right)$. We have shown ${ }^{40}$ that when using a $\mathrm{H}_{2}-\mathrm{CH}_{4}$ gas mixture instead of pure $\mathrm{H}_{2}$ for the reduction of an $\alpha-\mathrm{Al}_{1.9} \mathrm{Fe}_{0.1} \mathrm{O}_{3}$ solid solution, the pristine $\mathrm{Fe}$ nanoparticles formed in situ upon reduction of the very homogeneously dispersed surface $\mathrm{Fe}^{3+}$ ions are active at a size adequate for the catalytic growth of nanotubes. The resulting carbon nanotubes- $\mathrm{Fe}-\mathrm{Al}_{2} \mathrm{O}_{3}$ composite powder contains a huge amount of single- and multi-wall carbon nanotubes with a diameter in the $1.5-15 \mathrm{~nm}$ range. The nanotubes are arranged in bundles smaller than $100 \mathrm{~nm}$ in diameter and that may be up to $100 \mu \mathrm{m}$ long. We have proposed a method based on specific surface area measurements that allows a quantification of the amount of nanotubes in the composite powder and also produces a socalled quality value, a high quality denoting a smaller average tube diameter and/or more carbon in tubular form. The total bundle length in a gram of this powder was calculated to be equal to about $100000 \mathrm{~km}$. Indeed, the metal-oxide grains are uniformly covered by a web-like network of bundles and the powder is so densely agglomerated that it retains the shape of the reduction vessel when transferred in a storage box.

In order to increase the yield in Iijima's-type nanotubes in the composite powders, it is necessary to increase the number of active catalytic particles, while avoiding their coalescence and growth on the matrix surface, and to determine the appropriate experimental conditions of the reduction step. We have first investigated ${ }^{41}$ the influence of the crystallization level of an $\mathrm{Al}_{1.8} \mathrm{Fe}_{0.2} \mathrm{O}_{3}$ solid solution on the formation of carbon nanotubes upon selective reduction and we have shown that it is necessary to use the stable $\alpha-\mathrm{Al}_{1 \cdot 8} \mathrm{Fe}_{0.2} \mathrm{O}_{3}$ solid solution rather than the amorphous or $\eta$-solid solutions as starting material. Indeed, carbon is obtained essentially in the form of nanotubes in the former case, whereas important quantities of non-tubular carbon are produced in the latter cases. In addition, some carbon is entrapped within the oxide grains upon the crystallization of the amorphous or $\eta$ phases in $\alpha$-alumina during the reduction step. Starting from $\alpha-\mathrm{Al}_{1.8} \mathrm{Fe}_{0.2} \mathrm{O}_{3}$, we have also found that increasing the reduction temperature from 900 to $1000^{\circ} \mathrm{C}$ produces an increase in the amount of nanotubes but also a decrease in tube quality. ${ }^{41}$

The aim of this work is to determine the influence of the $\mathrm{Fe}$ content in the starting aluminahematite compounds on the amount and quality of carbon nanotubes in the composite powders prepared by reduction at 900 or $1000^{\circ} \mathrm{C}$. The microstructure and mechanical properties of carbon nanotubes- $\mathrm{Fe}-\mathrm{Al}_{2} \mathrm{O}_{3}$ massive materials prepared by hot-pressing these nanocomposite powders are reported in a companion paper. ${ }^{42}$

\section{Experimental}

The appropriate amounts of $\left(\mathrm{NH}_{4}\right)_{2}\left(\mathrm{C}_{2} \mathrm{O}_{4}\right), 2 \mathrm{H}_{2} \mathrm{O}$, $\mathrm{Al}\left(\mathrm{NO}_{3}\right)_{3}, 6 \mathrm{H}_{2} \mathrm{O}$, and $\mathrm{Fe}\left(\mathrm{NO}_{3}\right)_{3}, 9 \mathrm{H}_{2} \mathrm{O}$ were mixed in an aqueous solution heated at $60^{\circ} \mathrm{C}$. The obtained clear solution was cooled to room temperature and rapidly added to an alcoholic medium, in which precipitation of the mixed ammonium oxalate $\left(\mathrm{NH}_{4}\right)_{3}\left[\mathrm{Al}_{1-x} \mathrm{Fe}_{x}\left(\mathrm{C}_{2} \mathrm{O}_{4}\right)_{3}\right], n \mathrm{H}_{2} \mathrm{O} \quad(x=0 \cdot 02$, $0.05,0 \cdot 10,0 \cdot 15,0 \cdot 20)$ occured immediately. After filtering, washing and oven drying, the oxalate was finely ground and decomposed at $400^{\circ} \mathrm{C}$ for $2 \mathrm{~h}$, producing an $\mathrm{X}$-ray amorphous $\mathrm{Al}_{2-2 x} \mathrm{Fe}_{2 x} \mathrm{O}_{3}$ solid solution. ${ }^{32,43}$ This oxide was calcined in air for $2 \mathrm{~h}$ at $1100^{\circ} \mathrm{C}$ and was reduced in a $\mathrm{H}_{2}-\mathrm{CH}_{4}$ gas mixture $\left(6 \mathrm{~mol}_{0} \mathrm{CH}_{4}\right)$ during $4 \mathrm{~h}$ at $900^{\circ} \mathrm{C}$ or at $1000^{\circ} \mathrm{C}$, giving rise to the carbon-metal-oxide composite powders. A total reduction of the $\mathrm{Fe}^{3+}$ ions present in $\mathrm{Al}_{2-2 x} \mathrm{Fe}_{2 x} \mathrm{O}_{3}$ in metallic $\mathrm{Fe}$ would approximately yield a $y \mathrm{wt} \% \mathrm{Fe}-\mathrm{Al}_{2} \mathrm{O}_{3}$ composite $(y=100 x)$, not taking into account the presence of carbon. Thus, $y$ stands both for the cationic content $($ cat $\%)$ of $\mathrm{Fe}^{3+}$ ions in the initial oxalate or oxide and for the weight content ( $\mathrm{wt} \%$ ) of metallic phase in the composite powder, not taking into account the presence of carbon. For the sake of brevity, the composite powders will be denoted $y \mathrm{R} 900$ or $y \mathrm{R} 1000(2 \mathrm{R} 900,5 \mathrm{R} 900, \ldots, 20 \mathrm{R} 1000)$ according to their reduction temperature in the following section. The composite powders were oxidized in air at $850^{\circ} \mathrm{C}$ in order to eliminate all carbon, as required for the study. The powders were studied using X-ray diffraction (XRD) with Co $\mathrm{K} \alpha$ radiation $(\lambda=0.17902 \mathrm{~nm})$ and scanning 
electron microscopy (SEM). The specific surface areas of the oxide powders $\left(S_{\mathrm{ss}}\right)$, of the nanocomposite powders obtained after reduction $\left(S_{\mathrm{n}}\right)$ and of the powders oxidized at $850^{\circ} \mathrm{C}\left(S_{\text {on }}\right)$ were measured by the BET method using $\mathrm{N}_{2}$ adsorption at liquid $\mathrm{N}_{2}$ temperature. The carbon content was determined by flash combustion.

\section{Results and Discussion}

\subsection{Oxide powders}

XRD pattern analysis showed that calcination at $1100^{\circ} \mathrm{C}$ of the X-ray amorphous $\mathrm{Al}_{2-2 x} \mathrm{Fe}_{2 x} \mathrm{O}_{3}$ solid solutions produces monophase $\alpha$ $\mathrm{Al}_{2-2 x} \mathrm{Fe}_{2 x} \mathrm{O}_{3}$ (corundum) solid solutions when the Fe content is sufficiently low $(x \leq 0 \cdot 10)$. In contrast, the XRD patterns of specimens containing more $\mathrm{Fe}(x=0.15,0.20)$ present peaks characteristic of an $\alpha-\mathrm{Fe}_{2} \mathrm{O}_{3}$-rich solid solution in addition to those of the $\alpha-\mathrm{Al}_{2} \mathrm{O}_{3}$-rich solid solution (major phase). This traduces that some phase-partitioning occurs upon calcination in addition to crystallization, giving rise to a very intimately-mixed biphase product. These results are in agreement with earlier works. ${ }^{32,43,44}$

SEM observations reveal that the powders are made up of $10-20 \mu \mathrm{m}$ agglomerates of partially sintered submicronic primary grains, showing the so-called vermicular microstructure. ${ }^{45}$ The specific surface area measured for the calcined powders $\left(\mathrm{S}_{\mathrm{ss}}\right)$ are consistent with the crystallization level revealed by XRD analysis: 5.0, 3.4, 3.1, 4.4 and $4.5 \mathrm{~m}^{2} \mathrm{~g}^{-1}$ for the powders with $x=0.02,0.05,0 \cdot 10$, $0 \cdot 15,0 \cdot 20$, respectively.

\subsection{Composite powders}

\subsubsection{X-ray diffraction}

The XRD patterns of the nanocomposite powders prepared by reduction at $900^{\circ} \mathrm{C}$ of the solid solutions are shown in Fig. $1 \alpha-\mathrm{Fe}$ and $\mathrm{Fe}_{3} \mathrm{C}$ (cementite) are detected besides corundum, the intensity of the corresponding peaks increasing with the increase in $\mathrm{Fe}$ content. Earlier works ${ }^{32-35}$ have shown that the hydrogen reduction of the aluminabased solid solutions produces metallic Fe particles of nanometric size $(<10 \mathrm{~nm})$, which is reflected by the relatively large width [Figs 1(b) and 1(c)] of the $\alpha$-Fe (110) peak $\left(d_{110}=0.203 \mathrm{~nm}\right)$. Most of these particles are dispersed inside the grains of the $\mathrm{Al}_{2} \mathrm{O}_{3}$ matrix and therefore are thought to be protected from reacting with carbon when using a $\mathrm{H}_{2}-$ $\mathrm{CH}_{4}$ atmosphere. However, some particles, the number of which increases with the Fe content, are located at the surface of the matrix grains and can form $\mathrm{Fe}_{3} \mathrm{C}$. In the case of specimens prepared from

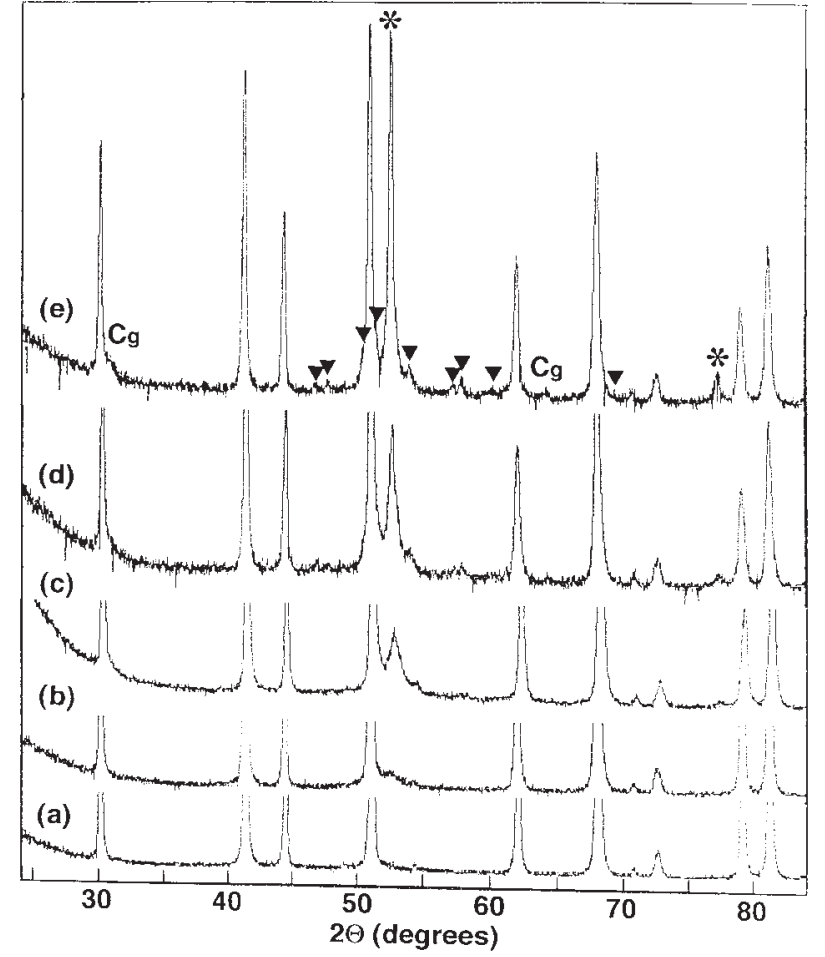

Fig. 1. XRD patterns of the nanocomposite powders prepared by reduction at $900^{\circ} \mathrm{C}$ : (a) $2 \mathrm{wt} \% \mathrm{Fe}$; (b) $5 \mathrm{wt} \% \mathrm{Fe}$; (c) $10 \mathrm{wt} \%$ $\mathrm{Fe} ;$ (d) $15 \mathrm{wt} \% \mathrm{Fe}$; (e) $20 \mathrm{wt} \% \mathrm{Fe} ; \alpha-\mathrm{Fe} ; \nabla: \mathrm{Fe}_{3} \mathrm{C} ; \mathrm{Cg}$ : corresponding to $d_{002}$ and $d_{004}$ in multi-wall nanotubes and/or in graphite. Un-indexed peaks: $\alpha$-alumina.

a mixture of an $\alpha-\mathrm{Al}_{2} \mathrm{O}_{3}$-rich solid solution and an $\alpha-\mathrm{Fe}_{2} \mathrm{O}_{3}$-rich solid solution (15R900 and 20R900), reduction of the latter oxide gives rise to another population of Fe particles ( $\geq 30 \mathrm{~nm}$ in size) also located on the surface of the alumina grains. ${ }^{32}$ This is reflected by the strong increase in the $\alpha$-Fe (110) peak intensity and the decrease in its width. Some of these particles may also react to form $\mathrm{Fe}_{3} \mathrm{C}$.

Wide peaks which could correspond to the distance between graphene layers $\left(d_{002}=0.34 \mathrm{~nm}\right.$ and $\left.d_{004}=0.17 \mathrm{~nm}\right)$ are also detected. Since neither the (hk0) nor the other (hkl) reflexions, which would have much smaller intensities for nanotubes as well as for graphite, ${ }^{46}$ are detected, it is not possible from the XRD patterns to discriminate between graphite and other graphenic forms of carbon such as nanotubes. Thus we have labelled these peaks $\mathrm{C}_{\mathrm{g}}$ $\left(\mathrm{C}_{\text {graphene }}\right)$.

$\mathrm{A} \mathrm{FeAl} 2 \mathrm{O}_{4}$ spinel phase, which is known to form at the $\mathrm{Fe} / \mathrm{Al}_{2} \mathrm{O}_{3}$ interface upon reduction in pure $\mathrm{H}_{2}$ at temperatures lower than $1000^{\circ} \mathrm{C}, 33,34,47,48$ is not detected in the R900 powders. One cannot rule out its presence in small quantities, because the $\mathrm{FeAl}_{2} \mathrm{O}_{4}$ main diffraction peaks $\left(d_{113}=0.245 \mathrm{~nm}\right.$, $d_{004}=0.202 \mathrm{~nm}$ and $\left.d_{044}=0.143 \mathrm{~nm}\right)$ may be masked by $\alpha-\mathrm{Fe}$ and Fe carbides peaks. However, neither $\mathrm{Fe}^{3+}$ nor $\mathrm{Fe}^{2+}$ ions were detected on the room temperature Mössbauer spectrum ${ }^{41}$ of the 10R900 composite, showing that the presence of $\mathrm{CH}_{4}$ in the reducing atmosphere strongly favours 
the formation of metallic Fe. Indeed, when reducing in pure $\mathrm{H}_{2}$, the $\mathrm{Fe}^{3+}$ ions substituting for $\mathrm{Al}^{3+}$ ions in the solid solutions were found to be totally reduced only after a treatment at $1300^{\circ} \mathrm{C}$ for 5 h. $^{35}$

Essentially similar features are observed on the $\mathrm{XRD}$ patterns of the nanocomposite powders prepared by reduction at $1000^{\circ} \mathrm{C}$ (Fig. 2), $\mathrm{Fe}_{5} \mathrm{C}_{2}$ being detected instead of $\mathrm{Fe}_{3} \mathrm{C}$. According to Wagman et al., ${ }^{49}$ the $\mathrm{CH}_{4}$ equilibrium content in $\mathrm{H}_{2}-\mathrm{CH}_{4}$ gas mixtures is lower at $1000^{\circ} \mathrm{C}$ (ca $0.9 \%$ ) than at $900{ }^{\circ} \mathrm{C}$ (ca $1.9 \%$ ). Thus, the $\mathrm{CH}_{4}$ sursaturation level in the gas mixture used in the present study $\left(6 \mathrm{~mol} \% \mathrm{CH}_{4}\right)$ is much higher at $1000^{\circ} \mathrm{C}$ (6.6 times more) than at $900^{\circ} \mathrm{C}$ (3.2 times more), which could account for the obtention of a higher carbide. It is noteworthy that Baker et al. ${ }^{50}$ have shown that metallic $\mathrm{Fe}$, and not an $\mathrm{Fe}$ carbide, is the active phase responsible for the formation of carbon nanofilaments. However, for a given Fe content, comparison of the $\alpha$-Fe (110) peak in the R900 and R1000 powders (Figs 1 and 2, respectively) shows that it is less intense for 2 and 5R900 than for 2 and 5R1000 and that it is wider and less intense for 10 and 15R900 than for 10 and 15R1000. These results indicate that the $\mathrm{Fe}$ surface particles are smaller in the R900 powders than in the corresponding R1000 powders, probably owing to an easier coalescence of the metal particles at the higher reduction temperature. For the same reason, the Fe surface particles are also probably smaller in 20R900 than in 20R1000. However, one can not distinguish this so easily on the XRD patterns because the $20 \mathrm{R} 900 \alpha-\mathrm{Fe}$ (110) peak is already very intense and thin.

$\gamma$-Fe may be present in all or some powders, but is extremely difficult to detect on the XRD patterns because the $\gamma$-Fe (111) diffraction peak $\left(d_{111}=0.208 \mathrm{~nm}\right)$ is probably masked by the basis of the corundum (113) peak $\left(d_{113}=0.2085 \mathrm{~nm}\right)$, the more so if $\mathrm{Fe}_{3} \mathrm{C} \quad\left(d_{210}=0.206 \mathrm{~nm}\right)$ or $\mathrm{Fe}_{5} \mathrm{C}_{2}$ $\left(d_{210}=0.208 \mathrm{~nm}\right)$ is present as well. However, a Mössbauer spectroscopy study ${ }^{41}$ of the 10 R900 and 10R 1000 composites has shown that ca $33 \%$ of the total $\mathrm{Fe}$-species is in the form of $\gamma-\mathrm{Fe}$, which could reflect the formation of a $\gamma-\mathrm{Fe}-\mathrm{C}$ alloy rather than pure Fe.

\subsubsection{Carbon content}

The carbon content measured in the nanocomposite powders $\left(C_{n}\right.$, Fig. 3$)$ is in the $0.6-5.4 \mathrm{t} \%$ range for the R900 powders, with a maximum for 15R900. $C_{n}$ is much higher for 15 and 20 R 900 than for the other specimens, a large gap being observed between 10 and 15 R900. For the R1000 powders, $C_{n}$ is in the $2.5-6.2 \mathrm{wt} \%$ range, with a maximum for $10 \mathrm{R} 1000$, this value being significantly higher

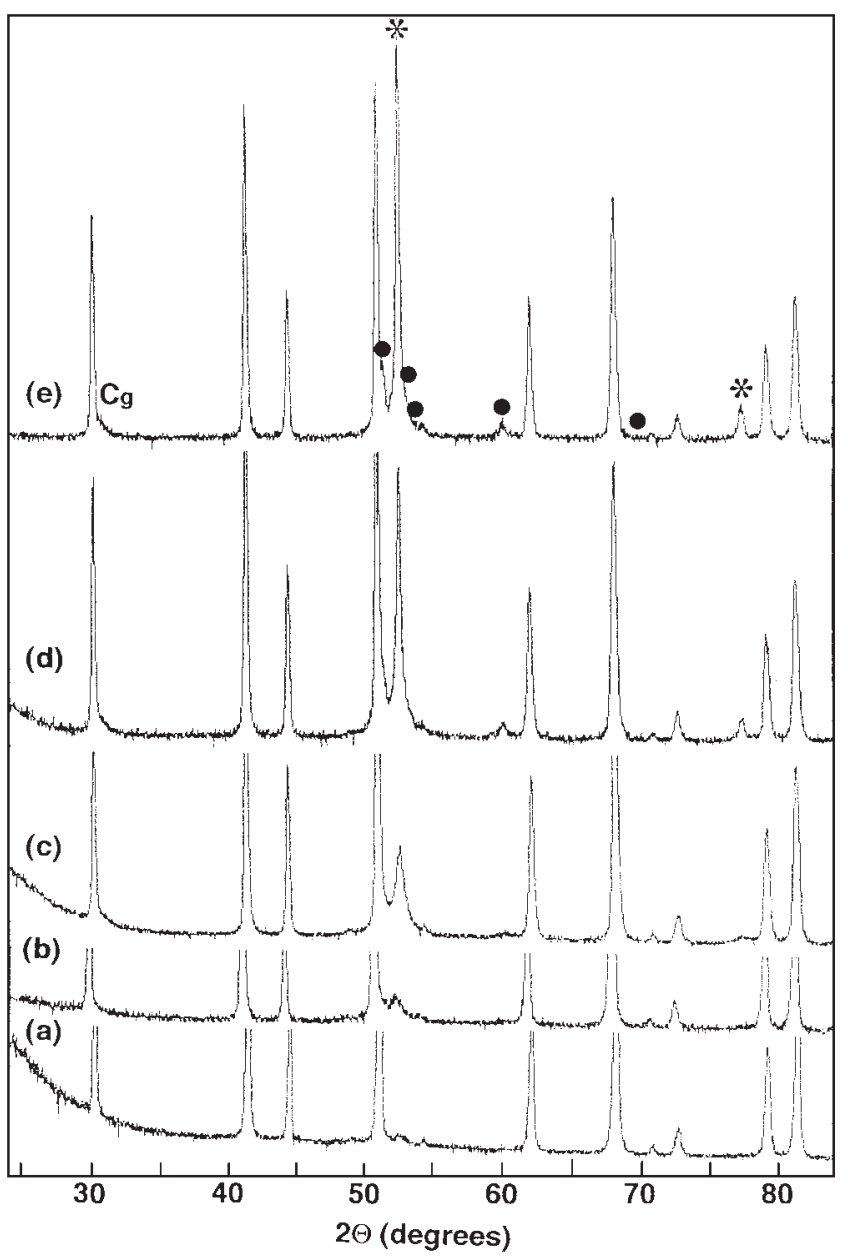

Fig. 2. XRD patterns of the nanocomposite powders prepared by reduction at $1000^{\circ} \mathrm{C}$ : (a) $2 \mathrm{wt} \% \mathrm{Fe}$; (b) $5 \mathrm{wt} \% \mathrm{Fe}$; (c) $10 \mathrm{wt} \% \mathrm{Fe}$; (d) $15 \mathrm{wt} \% \mathrm{Fe}$; (e) $20 \mathrm{wt} \% \mathrm{Fe} ; \alpha-\mathrm{Fe} ; 0: \mathrm{Fe}_{5} \mathrm{C}_{2}$; $\mathrm{Cg}$ : corresponding to $d_{002}$ in multi-wall nanotubes and/or in graphite. Un-indexed peaks: $\alpha$-alumina.

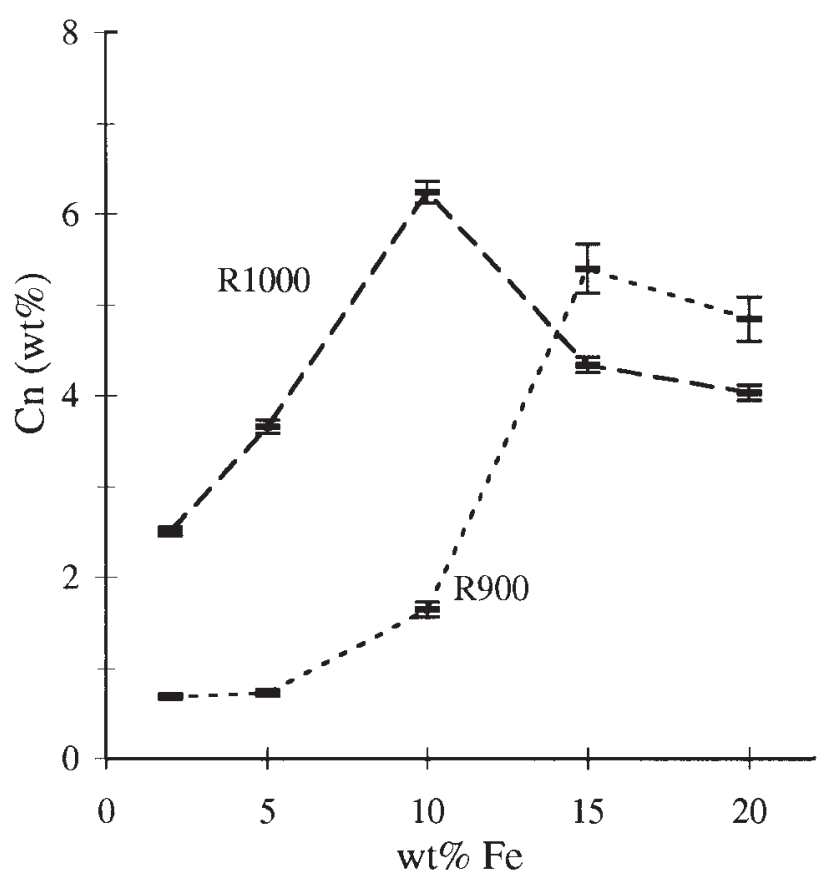

Fig. 3. The carbon content $\left(C_{n}\right)$ versus the Fe content in the nanocomposite powders. 
than for the other R1000 powders. For a given reduction temperature, the maximum corresponds to the $\mathrm{Fe}$ content that most favours $\mathrm{CH}_{4}$ decomposition in the present experimental condition, which could be related to the high number and the relatively small size of catalytic particles. Observing a decrease in $C_{n}$ for the higher metal contents (20R900 in one series, 15 and 20R1000 in the other) thus denotes that the surface particles in these specimens are less active for the catalytic decomposition of $\mathrm{CH}_{4}$, probably because they are much larger than in the other powders as shown by the XRD results. This could also explain why $C_{n}$ is lower for $15 \mathrm{R} 1000$ and $20 \mathrm{R} 1000$ than for $15 \mathrm{R} 900$ and 20R900. On the contrary, it is noteworthy that $C_{n}$ is significantly higher for 2,5 and 10R1000 than for 2, 5 and 10R900. This will be discussed later in this paper.

\subsubsection{Scanning electron microscopy}

In line with earlier results, ${ }^{40,41}$ SEM observations of the composite powders showed that the matrix grains, forming agglomerates ca $20 \mu \mathrm{m}$ large, are covered by a web-like network of carbon filaments not larger than $100 \mathrm{~nm}$ in diameter and several tens of micrometers long (Fig. 4). Note that owing to metallization the filaments appear slightly larger than they actually are. This web-like network allows the reduced powders to generally retain the shape of the reduction vessel when transferred in a storage box. TEM observations ${ }^{40,41}$ have evidenced that these long filaments are bundles of Iijima'stype carbon nanotubes and that the surface $\mathrm{Fe}$ or Fe carbide particles are covered by a few graphene layers. Much fewer filaments, with much smaller diameters, are detected in the 2R900 and 2R1000 powders [Fig. 4(a)] than in the other powders. This is reflected by a lower agglomeration state of these $2 \mathrm{wt} \% \mathrm{Fe}$ powders. But for all the other powders, SEM images do not allow to determine the difference in filament quantity with respect to the Fe content or the reduction temperature. In the $5 \mathrm{wt} \%$ Fe powders, most filaments have a diameter smaller than a few tens of nanometers [Fig. 4(b)], but some larger bundles looking like ribbons which are sometimes twisted to form buckles are also locally observed [Figs 4(c) and (d)]. The network of filaments on a porous matrix grain is clearly seen on the next image [10R900, Fig. 4(e)] and a low incidence image [10R1000, Fig. 4(f)] shows the extensive buckling of filaments at the surface of a matrix grain, demonstrating the high flexibility of carbon nanotubes and carbon nanotube bundles, as reported by many researchers. ${ }^{2-7}$ The 15 and $20 \mathrm{wt} \% \mathrm{Fe}$ powders differ from the other ones on two points: the presence of a higher proportion of large ribbon-like bundles [15R900, Fig. 4(g)] and that of some irregularly shaped filaments of large diameter and small length [20R900, Fig. 4(g)]. These large filaments [pointed by arrows in Fig. 4(h)] seem to be tubes containing a core probably made of $\mathrm{Fe}$ or Fe carbide. ${ }^{41}$

\subsubsection{Specific surface area}

As proposed elsewhere, ${ }^{40,41}$ the difference $\Delta S=$ $S_{n}-S_{\text {on }}$ between the specific surface area of the nanocomposite powder $\left(S_{n}\right)$ and that of the same powder after oxidation in air at $850^{\circ} \mathrm{C}\left(S_{\text {on }}\right)$ essentially represents the quantity of nanotube bundles in the composite powder. $\Delta S$ is plotted versus the Fe content both for the R900 and R 1000 composites in Fig. 5. The values are in the $1.2-2.6 \mathrm{~m}^{2} \mathrm{~g}^{-1}$ range for the $\mathrm{R} 900$ powders and in the $0.7-5 \mathrm{~m}^{2}$ $\mathrm{g}^{-1}$ range for the R1000 specimens. Both curves present a maximum for $10 \mathrm{wt} \% \mathrm{Fe}$. The evolution of $\Delta S$ with $\mathrm{Fe}$ concentration is similar to that of the carbon content $C_{n}$ (Fig. 3) except for $15 \mathrm{R} 900$ and 20R900, which contain much more carbon than 10R900 but present a lower $\Delta S$. Also, a $C_{n}$ higher for $2 \mathrm{R} 1000$ than for $2 \mathrm{R} 900$ is not reflected by a higher $\Delta S$. Interestingly, $\Delta S$ for $5 \mathrm{R} 1000$ and $10 \mathrm{R} 1000$ are significantly higher than for the other powders.

Calculations of $\Delta S / C_{n}$ may help to get a better understanding of the nature of the powders and explain some of the observed discrepancies. Indeed, the increase in specific surface area by gram of carbon, $\Delta S / C_{n}$, can be considered as representing the quality of the nanotubes, a higher figure for $\Delta S / C_{n}$ denoting a smaller average tube diameter and/or more carbon in tubular form, ${ }^{40,41}$ which we consider a better quality of carbon. $\Delta S /$ $C_{n}$ is plotted versus the $\mathrm{Fe}$ content both for the R900 and R1000 composites in Fig. 6. The values are in the $25-250 \mathrm{~m}^{2} \mathrm{~g}^{-1}$ range for the $\mathrm{R} 900$ powders but only in the $20-100 \mathrm{~m}^{2} \mathrm{~g}^{-1}$ range for the R1000 specimens, with a maximum for $5 \mathrm{wt} \% \mathrm{Fe}$ on both curves. It is noteworthy that the higher $\Delta S / C_{n}$ are found in specimens $(2,5$ and $10 \mathrm{R} 900)$ with a relatively low $\Delta S$ (Fig. 5) and thus that the increase in nanotube quantity observed in some powders (5 and 10R1000) upon the increase in reduction temperature is associated with a lower quality. Furthermore, the $\Delta S$ increase from 5 to $10 \mathrm{cat} \% \mathrm{Fe}$ in both series is also connected to a significant decrease in quality. However, $\Delta S / C_{n}$ for the 15 and $20 \mathrm{wt} \%$ Fe powders are similar whatever the reduction temperature.

\subsubsection{Discussion}

For a given reduction temperature, when the nanocomposite powders are prepared by reduction of a monophase $\alpha-\mathrm{Al}_{2-2 x} \mathrm{Fe}_{2 x} \mathrm{O}_{3}$ solid solution, as is the case for specimens containing 2, 5 and 

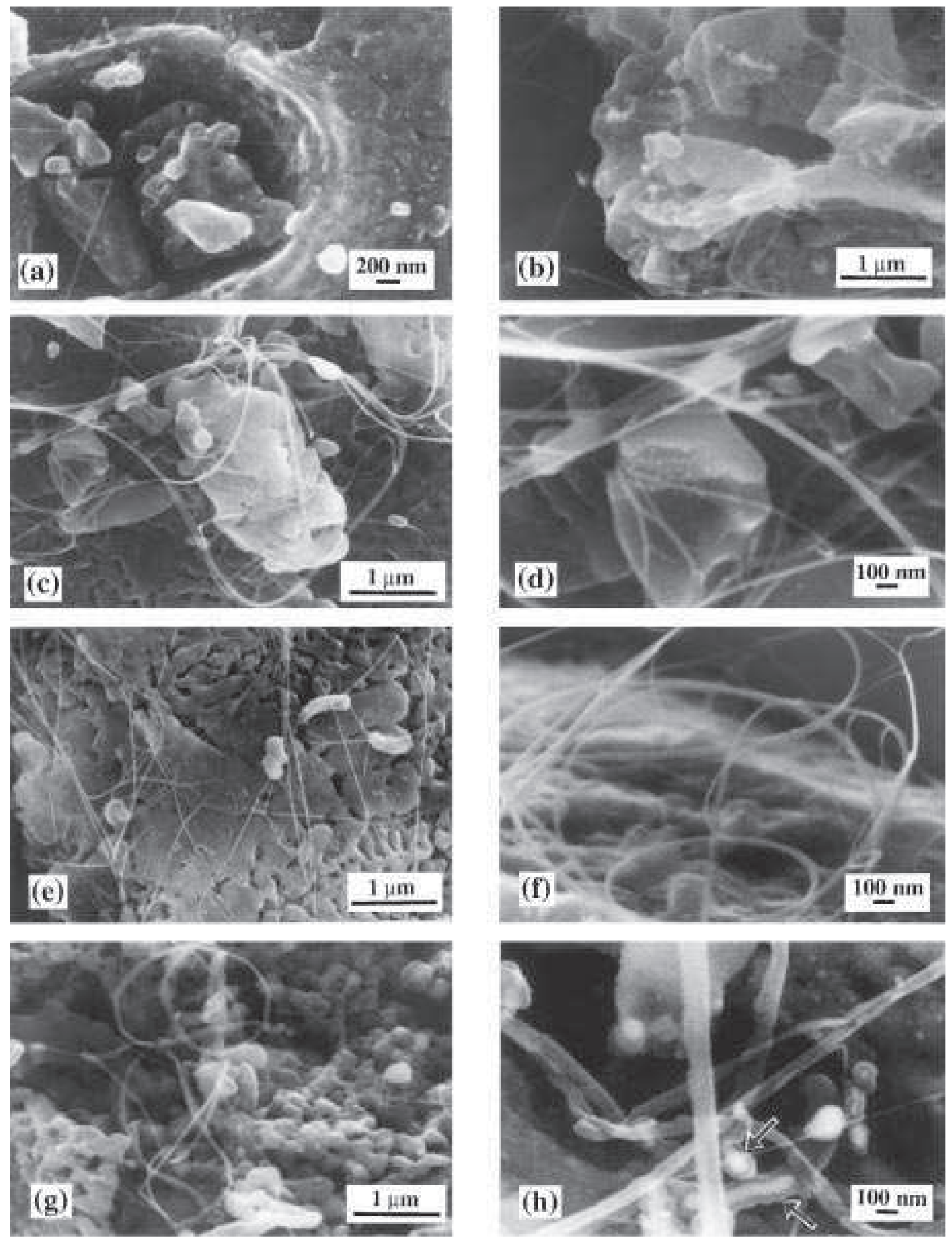

Fig. 4. SEM images of the nanocomposite powders: (a) 2R1000; (b) 5R1000; (c) 5R900; (d) higher magnification of (c); (e) 10R900; (f) 10R1000; (g) 15R900; (h) 20R900.

$10 \mathrm{wt} \% \mathrm{Fe}$, the carbon content $\left(C_{n}\right.$ Fig. 3$)$ and nanotube quantity ( $\Delta S$ Fig. 5$)$ increase with the $\mathrm{Fe}$ content. Indeed, more and more metal particles are present at the surface of the matrix grains and are available for $\mathrm{CH}_{4}$ decomposition, nanotube nucleation and possibly nanotube growth. The carbon nanotube quality $\left(\Delta S / C_{n}\right.$ Fig. 6) present a maximum for the composites containing only $5 \mathrm{wt} \% \mathrm{Fe}$. Since the internal diameter of the tube is that of the corresponding catalytic metal particle, higher quality tubes are obtained when using smaller metal particles. Indeed, as shown by the 


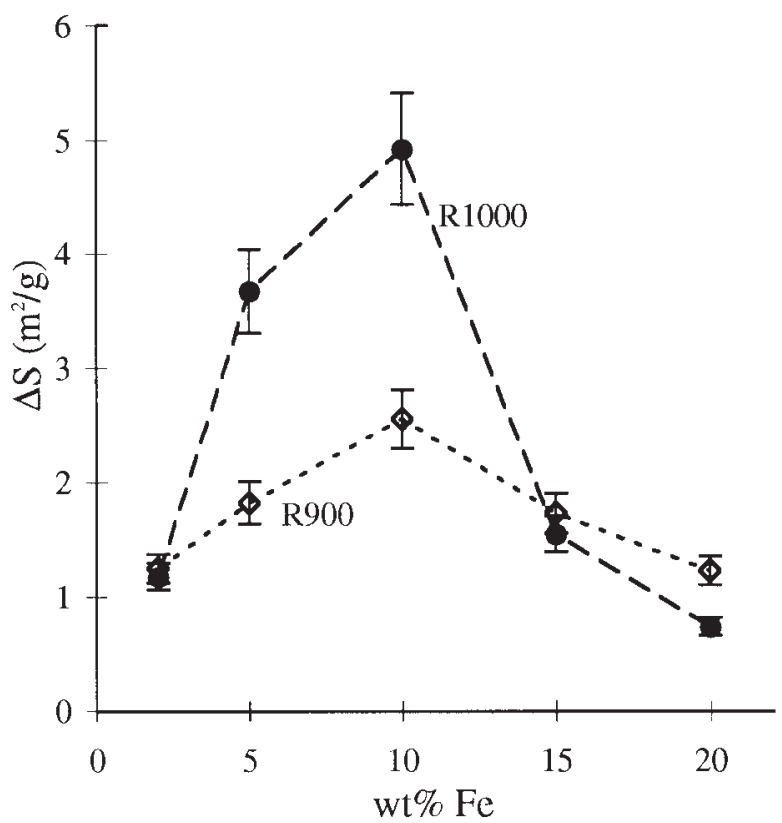

Fig. 5. $\Delta S=S_{n}-S_{\text {on }}$ versus the Fe content in the nanocomposite powders $\left(S_{n}\right.$ is the specific surface area of the nanocomposite powder and $S_{\text {on }}$ that of the powders oxidized at $\left.850^{\circ} \mathrm{C}\right)$.

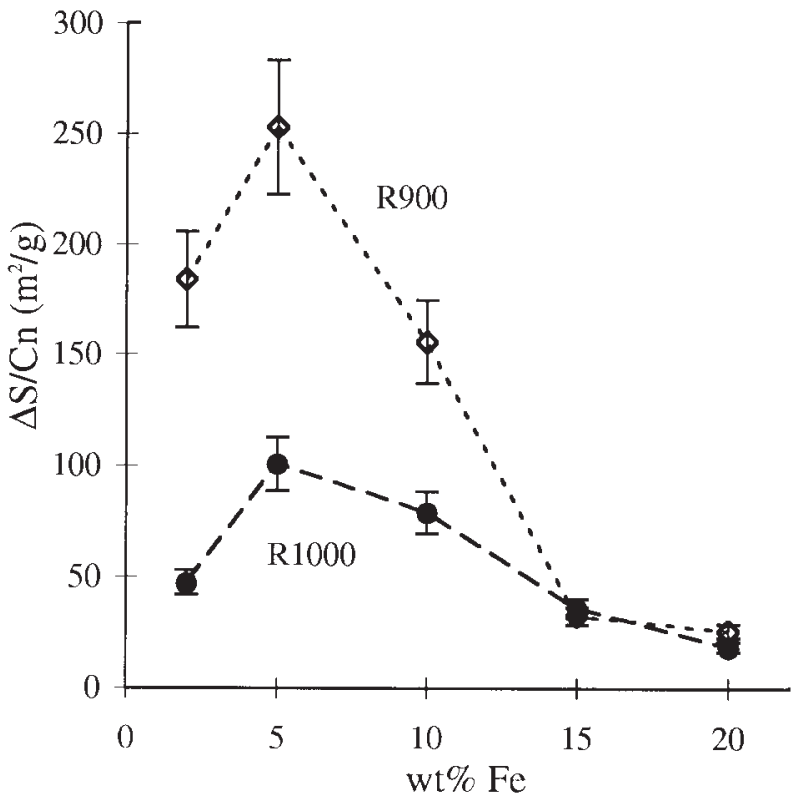

Fig. 6. $\Delta S / C_{n}$ versus the $\mathrm{Fe}$ content in the nanocomposite powders $\left(\Delta S=S_{n}-S_{\text {on }}\right.$ where $S_{n}$ is the specific surface area of the nanocomposite powder, $S_{\text {on }}$ that of the powders oxidized at $850^{\circ} \mathrm{C} ; C_{n}$ is the carbon content in the nanocomposite powder).

XRD results, the Fe surface particles are smaller for $5 \mathrm{wt} \% \mathrm{Fe}$ than for $10 \mathrm{wt} \% \mathrm{Fe}$, probably because of less coalescence on the matrix surface. However, for the $2 \mathrm{wt} \% \mathrm{Fe}$ powders, in which the Fe surface particles may be still more smaller, $\Delta S /$ $C_{n}$ is not higher (Fig. 6). This could be explained by a larger proportion of $\mathrm{Fe}$ carbide particles at the grain surface, but this can not be confirmed by XRD or Mössbauer spectroscopy because of the too low Fe content.
In contrast, when the nanocomposite powders are prepared by reduction of an intimate mixture of an $\mathrm{Al}_{2} \mathrm{O}_{3}$-rich oxide and an $\mathrm{Fe}_{2} \mathrm{O}_{3}$-rich phase (15 and $20 \mathrm{wt} \% \mathrm{Fe}$ powders), some differences in the $C_{n}$ evolution appears (Fig. 3), depending on the reduction temperature. $C_{n}$ weakly decreases from 15 to $20 \mathrm{wt} \% \mathrm{Fe}$ both for R900 and R1000, but with a large gain observed for 15R900 from the 10R900 value, in contrast to the evolution between 10R 1000 to $15 \mathrm{R} 1000$. In addition, both the quantity $(\Delta S$ Fig. 5$)$ and quality $\left(\Delta S / C_{n}\right.$ Fig. 6) decrease with the Fe content and are much lower than for $10 \mathrm{wt} \% \mathrm{Fe}$. In this case, the reduction of the $\mathrm{Fe}_{2} \mathrm{O}_{3}$-rich phase, which is known to be much easier than that of the $\mathrm{Al}_{2} \mathrm{O}_{3}$-rich oxide, ${ }^{35}$ produces $\mathrm{Fe}$ and $\mathrm{Fe}$ carbide particles that are too large for the nucleation of Ijima's-type ${ }^{1}$ nanotubes but rather appear to favour the growth of thick, short tubes as observed by SEM [Fig. 4(h)]. Moreover, Bi et al. ${ }^{51}$ have shown that nanometric cementite particles catalyze the growth of graphene layers. Such layers have been observed in our products by previous TEM studies. ${ }^{40,41}$ Thus, for the 15 and $20 \mathrm{wt} \% \mathrm{Fe}$ powders, the low values of both $\Delta S$ and $\Delta S / C_{n}$ could be explained by the low specific surface area of the carbon species other than nanotubes. From 10 to $15 \mathrm{wt} \% \mathrm{Fe}$, the difference between the R900 and R1000 powders may be a consequence of the difference in size of the Fe surface particles previously deduced from the XRD results. Indeed, in 15R900 these particles are probably still small enough to allow the growth of thick and short tubes, which are very numerous and represent a large quantity of carbon in comparison with the carbon nanotubes obtained in 10R900. In contrast, in 15R1000 the catalytic particles are probably too large and much of the carbon is deposited in the form of graphene layers, in relatively small quantity because of the low surface area of the large Fe particles.

For a given $\mathrm{Fe}$ content, the influence of the reduction temperature $\left(900\right.$ or at $\left.1000^{\circ} \mathrm{C}\right)$ on the observed differences in carbon content, quantity and quality of nanotubes is twofold in the present experimental conditions. Firstly, the increase in temperature favours the reduction of the ferric ions substituting in the alumina lattice and therefore the formation of catalytic metal particles. A previous study ${ }^{41}$ of the 10R900 and 10R1000 powders has shown that neither $\mathrm{Fe}^{3+}$ nor $\mathrm{Fe}^{2+}$ ions are detected on the room temperature Mössbauer spectra, revealing that the reduction into metallic $\mathrm{Fe}$ and/or $\mathrm{Fe}$ carbide is total in both compounds. Thus, assuming that it is the same for the 2 and $5 \mathrm{wt} \%$ specimens, we can infer that the number of metal particles at the surface of the matrix grains is roughly similar in both series for a given Fe content. Secondly, the increase 
in reduction temperature increases the $\mathrm{CH}_{4}$ sursaturation level in the gas atmosphere (from 3.2 to 6.6 times more), which could be beneficial for tube nucleation and growth. Indeed, with 2, 5 and $10 \mathrm{wt} \% \mathrm{Fe}$, both the carbon content $\left(C_{n}\right.$ Fig. 3) and nanotube quantity $(\Delta S$, Fig. 5) are higher for the R1000 powders than for the R900 ones, except for $\Delta S$ of $2 \mathrm{wt} \% \mathrm{Fe}$. However, the carbon quality $\left(\Delta S / C_{n}\right.$, Fig. 6) is much lower for the R1000 powders, which points out that a higher reduction temperature, and thus a higher $\mathrm{CH}_{4}$ sursaturation level in the present experimental conditions, also favours tube thickening and/or the deposit of much non-tubular carbon species.

For the 15 and $20 \mathrm{wt} \%$ Fe powders, despite the increase in the $\mathrm{CH}_{4}$ sursaturation level in the gas atmosphere from 900 to $1000^{\circ} \mathrm{C}$, both $C_{n}$ (Fig. 3) and $\Delta S$ (Fig. 5) are lower for the R1000 powders than for the corresponding R900 ones. As observed by XRD, the Fe surface particles are larger in the $\mathrm{R} 1000$ composites and $\mathrm{Fe}_{5} \mathrm{C}_{2}$ is found in the $\mathrm{R} 1000$ powders instead of $\mathrm{Fe}_{3} \mathrm{C}$ in the $\mathrm{R} 900$ ones. Thus, for the 20R1000 powder, as mentioned previously for $15 \mathrm{R} 1000$, the Fe surface particles are probably too large to even produce the thick, short tubes and they offer less surface for the deposition of the graphene layers. $\mathrm{Fe}_{5} \mathrm{C}_{2}$ surface particles may also be less catalyticaly active than $\mathrm{Fe}_{3} \mathrm{C}$ for the growth of graphene layers. But whatever the reduction temperature, both the quantity $(\Delta S$, Fig. 5) and quality $\left(\Delta S / C_{n}\right.$, Fig. 6) are low because of the growth of carbon species other than nanotubes. Increasing the $\mathrm{Fe}$ content in the composite powder up to a value higher than $10 \mathrm{wt} \%$ is not beneficial with respect to the formation of nanotubes.

In agreement with previous observations, ${ }^{41}$ the present results suggest that a compromise between a higher quantity of nanotubes and a higher carbon quality has to be found. High tube quantity is favoured by increasing the $\mathrm{Fe}$ content up to $10 \mathrm{wt} \%$ and performing the reduction at a higher temperature $\left(1000^{\circ} \mathrm{C}\right)$, whereas less $\mathrm{Fe}(5 \mathrm{wt} \%)$ and a lower reduction temperature $\left(900^{\circ} \mathrm{C}\right)$ are beneficial with respect to quality.

\section{Conclusions}

Oxides based on $\alpha$-alumina and containing various amounts of $\mathrm{Fe}(2,5,10,15$ and $20 \mathrm{cat} \%)$ were prepared by decomposition and calcination of the corresponding mixed-oxalates. Specimens in which the $\mathrm{Fe}$ content is below the solubility limit of hematite in $\alpha$-alumina $(\leq 10$ cat $\% \mathrm{Fe})$ are monophase solid solutions of general formula $\alpha-\mathrm{Al}_{2-2 x} \mathrm{Fe}_{2 x} \mathrm{O}_{3}(0 \leq x \leq 0 \cdot 1)$, whereas those containing more $\mathrm{Fe}$ rather consist in a very intimate mixture of an $\mathrm{Al}_{2} \mathrm{O}_{3}$-rich oxide and an $\mathrm{Fe}_{2} \mathrm{O}_{3}$-rich phase. Selective reduction of the oxides in a $\mathrm{H}_{2}-$ $\mathrm{CH}_{4}$ atmosphere produces nanometric Fe particles which are active for the in-situ nucleation and growth of carbon nanotubes, which are found to be arranged in bundles smaller than $100 \mathrm{~nm}$ in diameter and several tens of micrometers long. However, the so-obtained carbon nanotubes-Fe$\mathrm{Al}_{2} \mathrm{O}_{3}$ nanocomposite powders may also contain Fe carbide nanoparticles as well as undesirable thick, short carbon tubes and thick graphene layers covering the $\mathrm{Fe} / \mathrm{Fe}$ carbide nanoparticles.

Whatever the reduction temperature (900 or $1000^{\circ} \mathrm{C}$ ), it is preferable to reduce the monophase oxides rather than the mixtures with respect to the formation of Ijima's-type carbon nanotubes. The highest quantity of carbon nanotubes is obtained using $\alpha-\mathrm{Al}_{1.8} \mathrm{Fe}_{0.2} \mathrm{O}_{3}$ as starting compound, i.e. the maximum $\mathrm{Fe}$ concentration allowing to retain the monophase solid solution. A further increase in $\mathrm{Fe}$ content provokes the formation of a $\mathrm{Fe}_{2} \mathrm{O}_{3}$-rich phase through phase partitioning, which upon reduction produces too large $\mathrm{Fe}$ particles. The higher carbon quality, i.e. a smaller average tube diameter and/or more carbon in tubular form, is obtained with only $5 \mathrm{cat} \% \mathrm{Fe}\left(\alpha-\mathrm{Al}_{1.9} \mathrm{Fe}_{0 \cdot 1} \mathrm{O}_{3}\right)$. Indeed, the surface $\mathrm{Fe}$ nanoparticles formed upon reduction are probably slightly smaller, being less numerous and therefore less prone to coalescence, than those formed from $\alpha-\mathrm{Al}_{1 \cdot 8} \mathrm{Fe}_{0.2} \mathrm{O}_{3}$, thereby allowing the formation of carbon nanotubes of a smaller diameter.

For a given $\mathrm{Fe}$ content, lower than $10 \mathrm{cat} \%$, the increase in reduction temperature from 900 to $1000^{\circ} \mathrm{C}$ increases the quantity of carbon nanotubes, because the $\mathrm{CH}_{4}$ sursaturation level in the reducing atmosphere is higher at 1000 than at $900^{\circ} \mathrm{C}$. However, the simultaneous decrease in carbon quality points out that a higher reduction temperature also favours tube thickening and/or the deposit of much non-tubular carbon species in the present experimental conditions.

In agreement with previous observations, ${ }^{41}$ the present results suggest that a compromise has to be found to favour either the quantity of nanotubes or the carbon quality. However, a detailed study of the influence of the reduction temperature, the dwell time and the composition of the reduction atmosphere could yield an improvement in both the quantity and quality of carbon nanotubes in the nanocomposite powders.

\section{References}

1. Iijima, S., Helical microtubules of graphitic carbon. Nature, 1991, 354, 56-58.

2. Calvert, P., Strength in disunity. Nature, 1992, 357, 365-366. 
3. Ajayan, P. M., Stephan, O., Colliex, C. and Trauth, D., Aligned carbon nanotube arrays formed by cutting a polymer resin-nanotube composite. Science, 1994, 265 1212-1214.

4. Ruoff, R. S. and Lorents, D. C., Mechanical and thermal properties of carbon nanotubes. Carbon, 1995, 33, 925-930.

5. Sinnott, S. B., White, C. T. and Brenner, D. W., Properties of novel fullerene tubule structures: a computational study. Mat. Res. Soc. Symp. Proc., 1995, 359, 241-246.

6. Iijima, S., Brabec, C., Maiti, A. and Bernholc, J., Structural flexibility of carbon nanotubes. J. Phys. Chem., 1996, 104, 2089-2092.

7. Treacy, M. M. J., Ebbesen, T. W. and Gibson, J. M., Exceptionally high Young's modulus observed for individ ual carbon nanotubes. Nature, 1996, 381, 678-680.

8. Ebbesen, T. W. and Ajayan, P. M., Large-scale synthesis of carbon nanotubes. Nature, 1992, 358, 220-222.

9. Iijima, S. and Ichihashi, T., Single-shell carbon nanotubes of $1 \mathrm{~nm}$ diameter. Nature, 1992, 363, 603-605.

10. Bethune, D. S., Kiang, C. H., de Vries, M. S., Gorman, G., Savoy, R., Vazquez, J. and Beyers, R., Cobalt-catalysed growth of carbon nanotubes with single-atomiclayer walls. Nature, 1993, 363, 605-607.

11. Kiang, C. H., Goddard, W. A., Beyers, R., Salem, J. R. and Bethune, D., Catalytic effects of heavy metals on the growth of carbon nanotubes and nanoparticles. J. Phys. Chem. Solids, 1996, 57, 35-39.

12. Seraphin, S. and Zhou, D., Single-walled carbon nanotubes produced at high yield by mixed catalysts. Appl. Phys. Lett., 1994, 64, 2087-2089.

13. Ebbesen, T. W., Lezec, H. J., Hiura, H., Bennett, J. W., Ghaemi, H. F. and Thio, T., Electrical conductivity of individual carbon nanotubes. Nature, 1996, 382, 54-56.

14. Guerret-Piecourt, C., Le Bouar, Y., Loiseau, A. and Pascard, H., Relation between metal electronic structure and morphology of metal compounds inside carbon nanotubes. Nature, 1994, 372, 761-765.

15. Tohji, K., Goto, T., Takahashi, H., Shinoda, Y., Shimizu, N., Jeyadevan, B., Matsuoka, I., Saito, Y., Kasuhka, A., Oshuna, T., Hiraga, K. and Nishina, Y., Purifying singlewalled nanotubes. Nature, 1996, 383, 679.

16. Thess, A., Lee, R., Nikolaev, P., Dai, H., Petit, P., Robert, J., Xu, C., Lee, Y. H., Kim, S. G., Rinzler, A. G., Colbert, D. T., Scuseria, G. E., Tomanek, D., Fisher, J. E. and Smalley, R. E., Crystalline ropes of metallic carbon nanotubes. Science, 1996, 273, 483-487.

17. Witanachchi, S. and Mukherjee, P., Role of temporal delay in dual-laser ablated plumes. J. Vac. Sci. Technol. A, 1995, 3, 1171-1174.

18. Yacaman, M. J., Yoshida, M. M., Rendon, L. and Santiesteban, J. G., Catalytic growth of carbon microtubules with fullerene structure. Appl. Phys. Lett., 1993, 62, 657659.

19. Baker, R. T. K. and Rodriguez, N., Catalytic growth of carbon nanofibers and nanotubes. Mat. Res. Soc. Symp. Proc., 1994, 349, 251-256.

20. Ivanov, V., Fonseca, A., Nagy, J. B., Lucas, A., Lambin, P., Bernaerts, D. and Zhang, X. B., Catalytic production and purification of nanotubules having fullerene-scale diameters. Carbon, 1995, 33, 1727-1738.

21. Hernadi, K., Fonseca, A., Nagy, J. B., Bernaerts, D., Riga, J. and Lucas, A., Catalytic synthesis and purification of carbon nanotubes. Synthetic Metals, 1996, 77, 3134.

22. Fonseca, A., Hernadi, K., Nagy, J. B., Lambin, Ph. and Lucas, A., Model structure of perfectly graphitizable coiled carbon nanotubes. Carbon, 1995, 33, 1759-1775.

23. Sen, R., Govindaraj, A. and Rao, C. N. R., Carbon nanotubes by the metallocene route.. Chem. Phys. Lett., 1997, 267, 276-280

24. Herreyre, S. and Gadelle, P., Effect of hydrogen on the morphology of carbon deposited from the catalytic disproportionation of CO. Carbon, 1995, 33, 234-237.
25. Endo, M., Takeuchi, K., Kobori, K., Takahashi, K., Kroto, H. W. and Sarkar, A., Pyrolytic carbon nanotubes from vapor-grown carbon fibers. Carbon, 1995, 33, 873881.

26. Dai, H., Rinzler, A. G., Nikolaev, P., Thess, A., Colbert, D. T. and Smalley, R. E., Single-wall nanotubes produced by metal-catalyzed disproportion of carbon monoxide. Chem. Phys. Lett., 1996, 260, 471-475.

27. Tibbetts, G. G., Why are carbon filaments tubular? $J$ Crystal Growth, 1984, 66, 632-638.

28. Baker, R. T. K., Harris, P. S., Thomas, R. B. and Waite, R. J., Formation of filamentous carbon from iron, cobalt, cobalt and chromium catalysed decomposition of acetylene. J. Catal., 1993, 30, 86-95.

29. Amelinckx, S., Zhang, X. B., Bernaerts, D., Zhang, X. F., Ivanov, $\mathrm{V}$ and Nagy, J. B., A formation mechanism for catalytically grown helix-shaped graphite nanotubes. Science, 1994, 265, 635-639.

30. Oberlin, A., Endo, M. and Koyama, T., Filamentous growth of carbon through benzene decomposition. $J$. Crystal Growth, 1976, 32, 335-349.

31. Hernadi, K., Fonseca, A., Nagy, J. B., Bernaerts, D., Fudala, A. and Lucas, A. A., Catalytic synthesis of carbon nanotubes using zeolite support. Zeolites, 1996, 17, 416-423.

32. Devaux, X., Laurent, Ch. and Rousset A., , Chemical synthesis of metal nanoparticles dispersed in alumina. Nanostruct. Mater., 1993, 2, 339-346.

33. Laurent, Ch., Rousset, A., Verelst, M., Kannan, K. R., Raju, A. R. and Rao, C. N. R., Reduction behaviour of $\mathrm{Fe}^{3+} / \mathrm{Al}_{2} \mathrm{O}_{3}$ obtained from the mixed oxalate precursor and the formation of the $\mathrm{Fe}^{0}-\mathrm{Al}_{2} \mathrm{O}_{3}$ metal-ceramic composite. J. Mater. Chem., 1993, 3, 513-518.

34. Verelst, M., Kannan, K. R., Subbanna, G. N., Rao, C. N. R., Laurent, Ch. and Rousset, A., Investigations of the reduction behavior of iron-impregnated alumina gels $(\mathrm{Fe} /$ $\mathrm{AlOOH}$ ) and the formation of $\mathrm{Fe}^{0}-\mathrm{Al}_{2} \mathrm{O}_{3}$ metal-ceramic composite.. J. Mater. Res., 1992, 7, 3072-3079.

35. Laurent, Ch., Demai, J. J., Rousset, A., Kannan, K. R. and Rao, C. N. R., Fe- $\mathrm{Cr} / \mathrm{Al}_{2} \mathrm{O}_{3}$ metal-ceramic composites: nature and size of the metal particles formed during hydrogen reduction. J. Mater. Res., 1994, 9, 229-235.

36. Laurent, Ch., Blaszczyk, Ch., Brieu, M. and Rousset, A., Elaboration, microstructure and oxidation behavior of metal-alumina and metal-chromia nanocomposite powders. NanoStruct. Mater., 1995, 6, 317-320.

37. Quénard, O., Laurent, Ch., Brieu, M. and Rousset, A., Synthesis, microstructure and oxidation of $\mathrm{Co}-\mathrm{MgAl}_{2} \mathrm{O}_{4}$ and $\mathrm{Ni}-\mathrm{MgAl}_{2} \mathrm{O}_{4}$ nanocomposites powders. NanoStruct. Mater., 1996, 7, 497-507.

38. Quénard, O., De Grave, E., Laurent, Ch. and Rousset, A., Synthesis, microstructure and thermal behaviour of $\mathrm{Fe}_{0.65} \mathrm{Co}_{0.35}-\mathrm{MgAl}_{2} \mathrm{O}_{4}$ and $\mathrm{Fe}_{0.65} \mathrm{Ni}_{0.35}-\mathrm{MgAl}_{2} \mathrm{O}_{4}$ nanocomposites powders. J. Mater. Chem., 1997, 7, 2457-2467.

39. Carles, V., Brieu, M. and Rousset, A., Chemical synthesis and characterization of $\mathrm{Fe}_{0.65} \mathrm{Ni}_{0.35}-\mathrm{MgO}$ nanocomposite powders. NanoStruct. Mater., 1997, 8, 529-544.

40. Peigney, A., Laurent, Ch., Dobigeon, F. and Rousset, A., Carbon nanotubes grown in-situ by a novel catalytic method. J. Mater. Res., 1997, 12, 613-615.

41. Laurent, Ch., Peigney, A. and Rousset, A., Synthesis of carbon nanotubes- $\mathrm{Fe}-\mathrm{Al}_{2} \mathrm{O}_{3}$ nanocomposite powders by selective reduction of different $\mathrm{Al}_{1.8} \mathrm{Fe}_{0.2} \mathrm{O}_{3}$ solid solutions. J. Mater. Chem., 1998, 8, 1263-1271.

42. Laurent, Ch., Peigney, A., Dumortier, O. and Rousset, A. Carbon nanotubes-Fe-alumina nanocomposites. Part II: microstructure and mechanical properties of the hot-pressed composites. Journal of the European Ceramic Society, 1998, 18(14), 2005-2013.

43. Rousset, A. and Paris, J., Formation de solutions solides binaires et ternaires des sesquioxydes de chrome, aluminium et de fer. III-Le système $\mathrm{Fe}_{2} \mathrm{O}_{3}-\mathrm{Al}_{2} \mathrm{O}_{3}$. Bull. Soc. Chim. Fr., 1972, 10, 3729-3733. 
44. Muan, A. and Somiya, S., Phase equilibrium studies in the system iron oxide- $\mathrm{Al}_{2} \mathrm{O}_{3}-\mathrm{Cr}_{2} \mathrm{O}_{3}$. J. Am. Ceram. Soc., 1959, 42, 603-613.

45. Messing, G. L., McArdle, J. L. and Shelleman, R. A., The need for controlled heterogeneous nucleation in ceramic processing. Mat. Res. Soc. Symp. Proc., 1986, 73, 471480.

46. Seshadri, R., Govindaraj, A., Aiyer, H. N., Sen, R., Subbanna, G. N., Raju, A. R. and Rao, C. N. R., Investigations of carbon nanotubes. Current Sci., 1994, 66, 839847.

47. Marchand, A., Devaux, X., Barbara, B., Mollard, P., Brieu, M. and Rousset, A., Microstructural and magnetic characterization of alumina-iron nanocomposites. J. Mat. Sci., 1993, 28, 2217-2226.
48. Devaux, X., Laurent, Ch., Brieu, M. and Rousset, A., Iron-alumina interface in ceramic matrix nanocomposites. J. All. Comp., 1992, 188, 179-181.

49. Wagman, D. D., Kirpatrick, J. E., Taylor, W. J., Pitzer, K. S. and Rossini, F. D., Heats, free energies, and equilibrium constants of some reactions involving $\mathrm{O}_{2}, \mathrm{H}_{2}, \mathrm{H}_{2} \mathrm{O}$, C, $\mathrm{CO}, \mathrm{CO}_{2}$ and $\mathrm{CH}_{4}$. J. Res. Natl. Bur. Stand., 1945, 34, $143-161$.

50. Baker, R. T. K., Alonzo, J. R., Dumesic, J. A. and Yates, D. J. C., Effects of the surface state of iron on filamentous carbon formation. J. Catal., 1977, 74, 82-84.

51. Bi, X. X., Ganguly, B., Huffman, G. P., Huggins, F. E., Endo, M. and Eklund, P. C., Nanocrystalline $\alpha$-Fe, $\mathrm{Fe}_{3} \mathrm{C}$ and $\mathrm{Fe}_{7} \mathrm{C}_{3}$ produced by $\mathrm{CO}_{2}$ laser pyrolysis. J. Mater. Res., 1993, 8, 1666-1674. 